\title{
ガス爆発現象の火炎伝播速度への依存性 Effect of Flame Propagation Speed on Gas Explosion
}

\author{
○正茂木 俊夫（東大院）金 佑勁（東大院） \\ 土橋 律 (東大院)
}

Toshio Mogi, Wookyong Kim and Ritsu Dobashi

The University of Tokyo, 7-3-1 Hongo, Bunkyo-ku, Tokyo 113-8656

\begin{abstract}
In the present study, the influences of flame propagation speed on the intensity of blast wave during unconfined gas explosions have been examined experimentally. The various scale tests of hydrogen/air deflagrations conducted. Results demonstrated the flame wrinkled and accelerated due to hydrodynamic instability with the flame scale and thereby the overpressure rapidly increased. In particular, the intensity of blast wave compared with the Peclet number defined as dimensional flame radius when the unburned mixture is combusted. The results of comparison show the dimensionless overpressure increased with the Peclet number, because of flame acceleration due to the hydrodynamic instability, as the explosion scale became larger.
\end{abstract}

Key Words: Gas explosion, Flame propagation, Blast wave, Hydrogen

\section{1. 緒言}

可燃性ガスはプラント等に限らず，，般家庭など社会で 広く利用されている．近年では，水素燃料電池自動車の開 発が進み，自動車用燃料としてさらに普及すると予想され る.しかしながら，可然性ガスは漏えいして懪発事故が発 生する危険性があるため, 可燃性ガスの利用にあたっては， 効果的な安全対策や万が一事故が発生した場合の危険性評 価や被害低減対策などが重要となる。最近は危険性評価と してリスク詊価がしばしば用いられている。 リスク詊価に は, 想定される危険現象が発生した場合に予想される被害 の大きさすなわち影響度が重要な情報であり，適正な評価 が求められる，爆発災害では，爆風の発生によって広範囲 に大きな被害が発生する可能性があるため, 爆風威力の評 価についてさまざまな研究が行われている(1).

大規模なガス爆発現象では，火炎伝播の加速が発生する ことが知られている(2). 音響学理論 ${ }^{(3)}$ によると爆風威力は 火炎伝播速度と密接に関係することから，爆風に上る影響 適正に予測才るためには，火炎伝播の加速現象亡爆風举動 の関係を埋解する必要がある，そこで本研究では，水素ガ スを用いて開放空間におけるガス爆発実験を行い, 火炎伝 播および爆風举動について計測し, 爆風圧の火炎伝播速度 への依存性について考察した。

\section{2. 実験装置および方法}

開放空間に扩ける可燃性ガス/空気混合気の火炎伝播举 動おうよび爆風挙動を調べるため，実験室䙺模の小䙺模実験 から，屋外で行う大規模実験まで行った．可燃性ガスとし て水幸を用いた，小規模実験では，開放空間を模擬するた めに，所定の濃度の混合気を供給してシャボン玉(直径 100 $\left.\mathrm{mm}, \quad V=0.001 \mathrm{~m}^{3}\right)$ を形成し, シャボン玉の中心で火花点 火により着火させた。一方、大規模実験は, 1 辺が $1 \mathrm{~m}(V=$ $\left.1 \mathrm{~m}^{3}\right)$ および $3 \mathrm{~m}\left(V=27 \mathrm{~m}^{3}\right)$ の立方体型枕に薄いビニルシー 卜を張り付けて形成した空問内に水素を供給して，所定り 濃度になるように調整し，空問内の中心で着火させた。

火炎伝播举動の計測は，小規模実験ではシュリーレン法 を用いて高速度カメラで撮影し，大規模実験では，水素火 炎は不輝炎であるため，モノクロ高速度カメラに短波長力 ットフィルター(カット波長< $990 \mathrm{~nm})$ 取り付けて，火炎 からの赤外発光を撮影した. 爆風は, ピエゾ型圧カセンサ
一(PCB，106B52 )およびマイクロフォン(PCB，377B02)で 同時に計測し，出力をデータ記録装置(横河電機, DL850) で記録した。

\section{3. 実験結果および考察}

規模が烡なる実験で撮影された火炎伝播の様子を Fig. 1 に示す，水素濃度は化学量論組成濃度である．(a)はシュリ 一レン画像であり, (b)亡(c)㤌火炎背後の高温の水分子から 放射された赤外線を撮影したものである. シュリーレン画 像では，燃焼初期から火炎面に筋状の乱れが確認でき，比 較的火炎が小さいときから乱れが発生していることがわか る。一方，屋外で撮影された画像では，乱れの詳細までは 確認できないが, 火炎からの赤外線を撮影することにより， 火炎伝播の様子を観察寸るのに1分な画像を得ることがで きた.

火炎伝播データから算山した火炎伝播速度と計測された 爆風圧の経時変化去 Fig. 2 に示寸. 水素濃度恃化学量論組 成濃度である，爆風圧は，換算距離 $\left(R / R_{0}\right)$ が 0.8 から 0.9 の 範囲で測定されたものである。ここで， $R$ は点火位置から の距離, $R_{0}$ は次式で定義される。

$$
R_{0}=\left(E / p_{0}\right)^{1 / 3}
$$
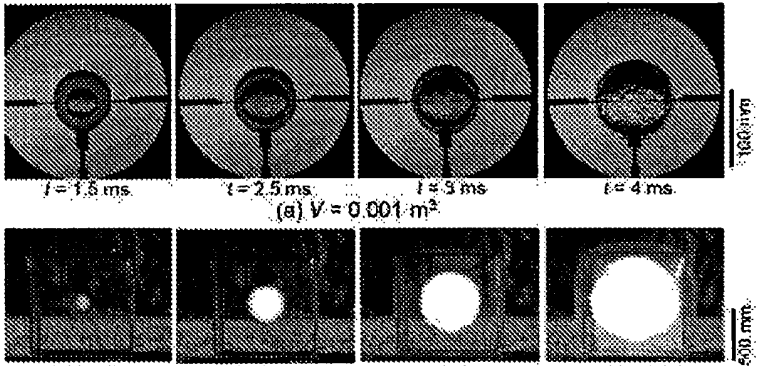

(a) $y=0.001 \mathrm{~m}^{2}$
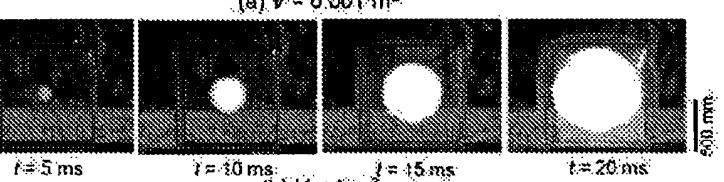

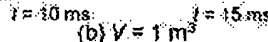

$t=20 \mathrm{kis}$
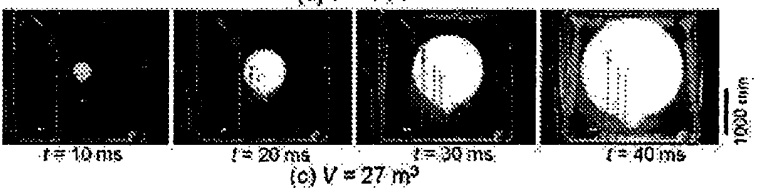

$\mathrm{V}=27 \mathrm{~m}$

Fig. 1 Comparison of flame propagation image of hydrogen-air mixture at stoichiometric concentration. 
ここで， $E$ は混合気の総発熱量， $p_{0}$ は大気圧である。

スケールが大きくなるにしたがって火炎伝播速度が速くな っている，つまり加速していることが確認できる。

一方, 爆風威力に及ぼす火炎伝播の影響を考察するため に, 次の式を用いた。

$$
p=\frac{\rho}{R} \frac{(\varepsilon-1)}{\varepsilon}\left\{2 r \varepsilon^{2} S^{2}+r^{2} \frac{d S}{d t}\right\}
$$

ここで, $\rho$ は未燃ガ久の密度, $R$ は点火位置からの距離, $\varepsilon は$ 膨張率, $\boldsymbol{r}$ は火炎半径, $S$ は燃焼速度である ${ }^{[3]}$. 燃焼速度が一 定であると仮定して，式(2)に実測した燃焼速度を代入して 得られた爆風生の訃算值を示才゙。着火からの時間が短い場 合，才抽水炎伝播のごく初期においては，燃焼速度を 一定とした仮定とほぼ一致する。つまり，火炎伝播の加速 は見られていない。しかし，火炎の規模が大きくなるにつ れて計算值から大きくずれる傾向がみられ，爆風圧に対し て，火炎伝播の加速が人きく影響していることがわかる。

Fig. 2(b) および(c) はビニルハウスを用いた屋外実験で の爆風圧の経時変化を示しているが, 波形の急激な立ち上 がりは，ビニルハウスの破膜により火炎が乱れて急速に燃 焼したことにより圧力が上昇したと思われる。換算距離で はほぼ同程度であり，ビーク過压もほぼ同程度であるにも 関わらず，破膜直前の爆風厌に注日寸ると，計算值との差 に大きな違いが見りれることがわかる.これまでの砳究で， 火炎半怿が増大寸ると流体力学的不安定性が顕著になるこ とを報告しているが，火炎規模の増大が爆風圧に対しても 顕著に影響することが考えられる。

次に最大爆風圧について考察する.Fig. 3 は混合気が完 全に燃焼したときの火炎半径を火炎厚さで除して無次元化 した Peclet 数 $P e_{\mathrm{q}}$ と, 実験值の最大爆風庄 $P_{\mathrm{t}}$ 上燃焼速度一 定上して求められる最大爆風庄 $P_{1}$ との比 $P_{\mathrm{t}} / P_{1}$ との関係を 示す．屋外実験の場合は立方体形状であるが，球体に近似 して求ぬた. Peclet 数が大きくなると $P_{\mathrm{t}}$ と $P_{1}$ の)比が指数関 数的に大きくなっていくことがわかる.これは，火炎が大 きくなると流体力学的不安定性による火炎の自発的な乱れ が大きくなり，火炎の伝播が加速していることが影響して いると考えられる。

\section{4. 結言}

開放空間におけるガス爆発実験を行い，火炎伝播挙動と 爆風挙動について検討した.火炎の規模が大きくなるほど, 爆風挙動に対して火炎伝播の加速の影響が顕著になる。し たがって，爆発の規模が大きくなるほど, 爆風威力の予測 に際し，火炎伝播の加速を考虑する必要がある.

\section{謝辞}

本研究は，科研費基盤研究(A)No.23241051 の助成产受け て実施した。ここに謝意を示す.

\section{参考文献}

(1)R. Dobashi, et al, Proc. Combust. Inst., 33(2011), 2295-2301.

(2)金, 他, 日木燃焼学会誌, 56 (2014), 74-79.

(3)W. Kim, et al, J. Loss Prevention in the Process Industries. .

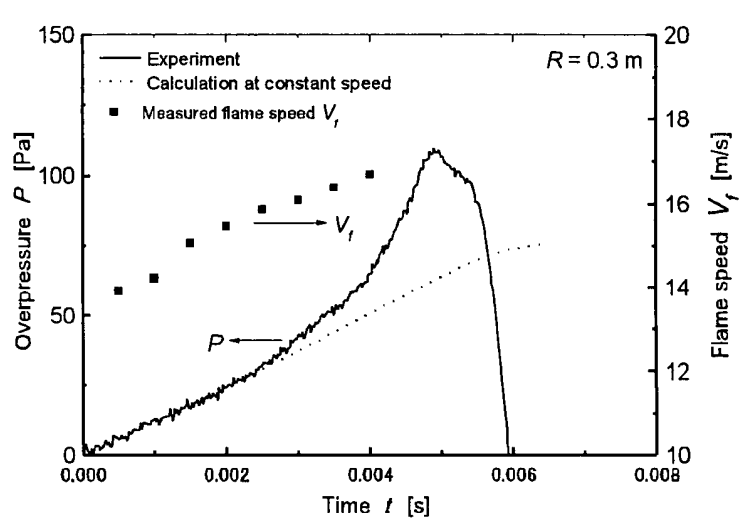

(a) $V=0.001 \mathrm{~m}^{3}$

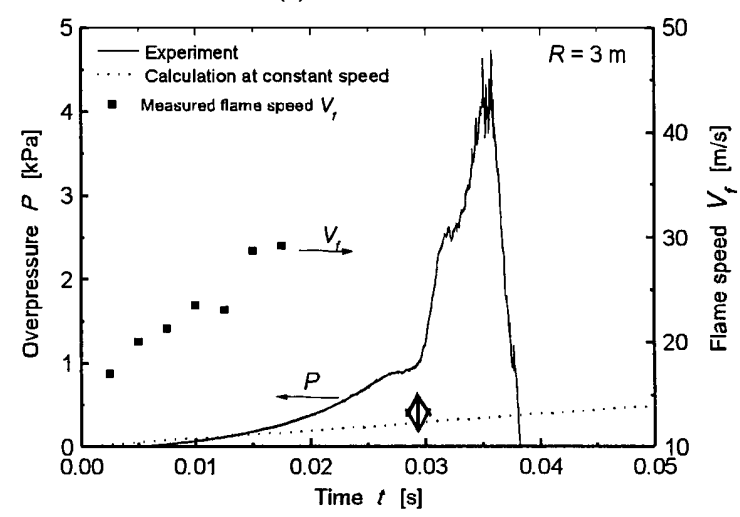

(b) $V=1 \mathrm{~m}^{3}$

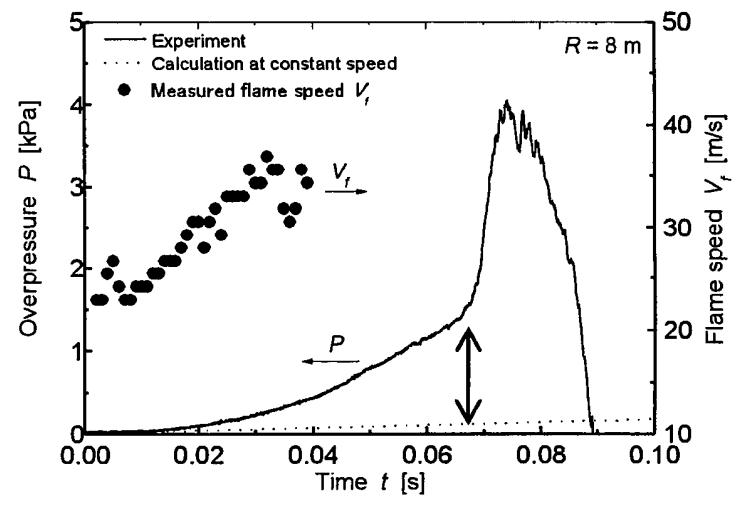

(c) $V=27 \mathrm{~m}^{3}$

Fig. 2 Time histories of overpressure and flame speed.

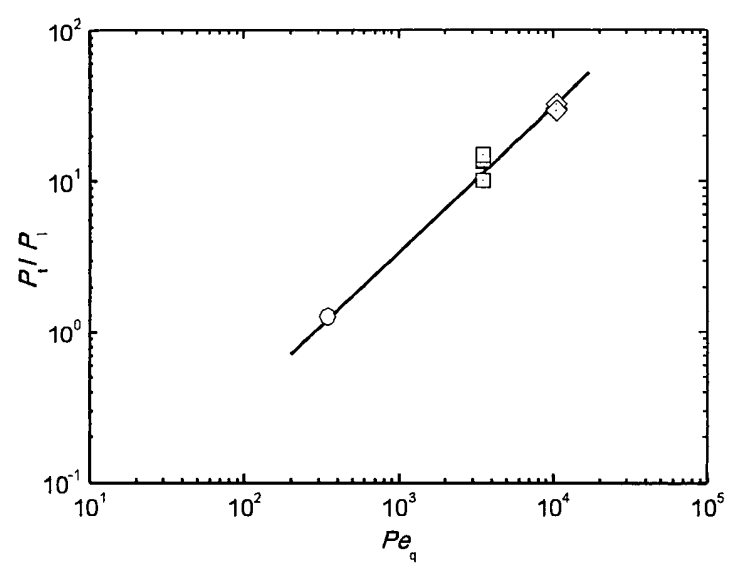

Fig. 3 Relation between $P e_{\mathrm{q}}$ and $P_{\mathrm{t}} / P_{1}$. 